\title{
Effect of Students' Attitude on Environmental Factors and Green Practice (Reduce, Recycle \& Reuse)
}

Musramaini Mustapha, Mas'udah Asmui, Sharifah Norhuda Syed Wahid, Suhanom Mohd Zaki, and Saifudin Razali

To Link this Article: http://dx.doi.org/10.6007/IJARBSS/v11-i3/8974

DOI:10.6007/IJARBSS/v11-i3/8974

Received: 04 February 2021, Revised: 28 February 2021, Accepted: 09 March 2021

Published Online: 17 March 2021

In-Text Citation: (Mustapha et al., 2021)

To Cite this Article: Mustapha, M., Asmui, M., Wahid, S. N. S., Zaki, S. M., \& Razali, S. (2021). Effect of Students' Attitude on Environmental Factors and Green Practice (Reduce, Recycle \& Reuse). International Journal of Academic Research in Business and Social Sciences, 11(3), 591-600.

Copyright: (C) 2021 The Author(s)

Published by Human Resource Management Academic Research Society (www.hrmars.com)

This article is published under the Creative Commons Attribution (CC BY 4.0) license. Anyone may reproduce, distribute, translate and create derivative works of this article (for both commercial and non-commercial purposes), subject to full attribution to the original publication and authors. The full terms of this license may be seen

at: http://creativecommons.org/licences/by/4.0/legalcode

Vol. 11, No. 3, 2021, Pg. 591 - 600

Full Terms \& Conditions of access and use can be found at http://hrmars.com/index.php/pages/detail/publication-ethics 


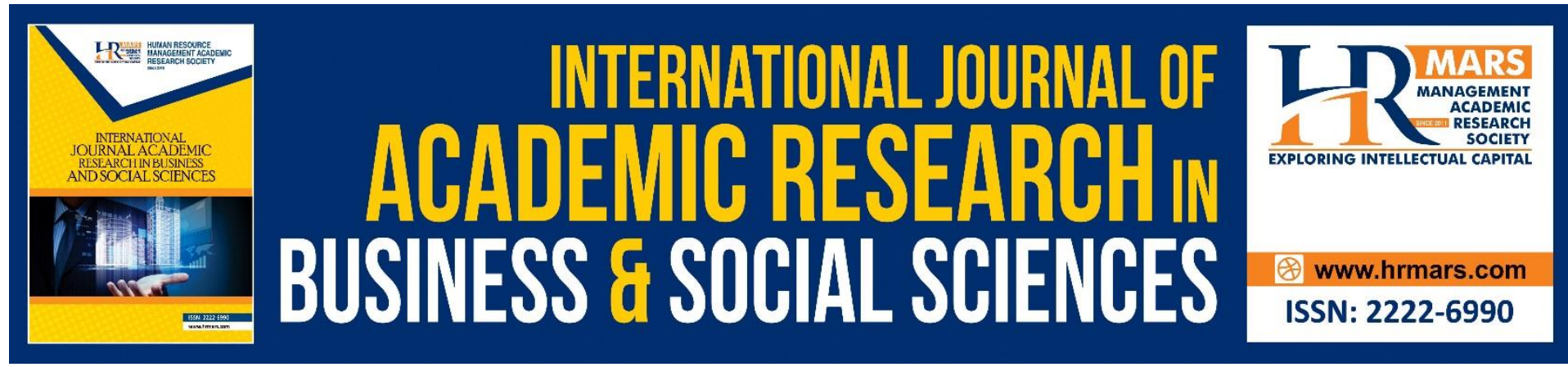

\title{
Effect of Students' Attitude on Environmental Factors and Green Practice (Reduce, Recycle \& Reuse)
}

\section{Musramaini Mustapha ${ }^{1}$, Mas'udah Asmui ${ }^{1}$, Sharifah Norhuda Syed Wahid ${ }^{3}$, Suhanom Mohd Zaki ${ }^{1}$, and Saifudin Razali ${ }^{2}$}

${ }^{1}$ Faculty of Business Management, Universiti Teknologi MARA Pahang, Bandar Tun Abdul Razak Jengka, Pahang, Malaysia, ${ }^{2}$ Faculty of Electrical and Electronics Engineering, Universiti

Malaysia Pahang, Pekan, Pahang, Malaysia, ${ }^{3}$ Faculty of Computer and Mathematical

Sciences, Universiti Teknologi MARA Pahang, Bandar Tun Abdul Razak Jengka, Pahang, Malaysia

Email:musra_08@uitm.edu.my,mas_as@uitm.edu.my, suhanom@uitm.edu.my, saifudin@ump.edu.my,sha_norhuda@uitm.edu.my

\begin{abstract}
Going green must derive from green practice. The green practice involves $3 R$ process that focus on effort to reduce, recycle, and reuse. The recycle issue always became on top in the list, indirectly other effort reduce and reuse also important toward environmental concerns. Thus, the researchers found it vital to conduct a study on the green practice process related to $3 R$ (reduce, recycle, and reuse) based on affective and cognitive environmental, also interested to assess the role of students' attitude as a mediator in the relationship between the variables of interest. For that reason, 112 respondents were selected to participate and all of them completed set of questionnaires. The findings show that, only affective environmental and students' attitude have a significant and positive influence towards $3 R$ processes. In addition, students' attitude does not mediate the relationship between affective environmental and $3 R$ since the indirect effect is smaller than direct effect. This finding determine Universiti Teknologi MARA students are putting their efforts and support toward environmental concern. Thus, business industry and tertiary institutional may need to collaborate to start encouraging their customers move effort toward $3 \mathrm{R}$ process to support green practice.
\end{abstract}

\section{Introduction}

Going green is not just recycling all the products that we used, it involves more effort than this. Each person playing the important roles to maintain, sustain and protecting the environment. A study from Chua et al (2011) said the prospect of a green future in Malaysia is very bright, meanwhile pursuing green technology in economic and social developments not only helps to sustain the non-renewable fuels, safeguards and minimises the environmental degradation due to carbon emissions, it also creates a strong green economy and industry, in line with the country's vision as well as the rest of the world economies. The 
environmental issues have been brought into many discussions. Previous studies in entrepreneurship education also mentioned that emotions have received much less attention from researchers (Kurczewska et al., 2017) compared to cognition. According to Wolski (2009) several universities around the world have made commitments to promote strategies for creating more sustainable universities, through their teaching, their campuses and their management. Activities of going green held in $3 \mathrm{R}$ program that comprising activities of reduce, recycle and reuse. Even though the trend of sustainable development has not yet fully permeated to all disciplines, academics, and university leaders, many universities have become engaged in it (Lozano et al., 2013). Furthermore, trend in business have been seen having an increasing awareness on the significance of going green. Savolainen (2015) also stated in modelling information behaviour, the main emphasis on its cognitive dimensions while the role of which affective factors such as emotions and feelings has remained secondary.

\section{Literature Review \\ Affective Environmental}

Affection is regarded as a subjective concept concerning both dispositional affect (personality that is more stable), specific emotion (intense and short-term), and mood (low intensity but lasting, resulting from stimuli) (Cardon et al., 2012; Kurczewska et al., 2017; Mustapha et al., 2018). While, affective dispositions can be defined as affective reactions that individuals display towards environmental deterioration (Hines, Hungerford and Tomera, 1987; Kals and Maes, 2002; Kollmuss and Agyeman, 2002; Fettahlioglu, Timur and Timur; 2016). In other words, affective tendencies are the state of the individual to be sensitive both to the environment and the environmental problems and to take moral and ethical values of the society into consideration while making decisions about the environment and showing responsibilities towards the environment (Roth, 1992; Fettahlioglu et al., 2016).

\section{Cognitive Environmental}

Cognition is a term for the process of gaining awareness in which individuals recognize and seek information. It relates to perceiving, recognizing, conceiving, judging, and reasoning. The cognitive construct consists of declarative and procedural knowledge. The difference between these two is that the first refers to the method of link the concepts together and the second is the abilities to apply this knowledge. Dieser (2015) mentioned positive correlations between pro-environmental preferences and scores on a knowledge test and negative correlations with egocentric environmental attitudes and knowledge scores. Furthermore, Bogner (2016) reported a connection between environmental attitudes and knowledge where positive relationships between knowledge and environmental perception were found. Meanwhile, Mustapha et al (2018) in their study has found that it is not hidden fact that environmental affection highly affected towards student's environmental attitude compared to the environmental cognition.

\section{Students' Attitude}

Attitudes about littering include feelings scepticism about whether littering is truly a deviant behaviour, if it seriously harmful to the environment, and whether it is worth mitigating (Keep Louisiana Beautiful, 2017). In one of public Malaysian university, mentioned the students' positive littering behaviour was high due to lack of littering facility provided, followed by low littering awareness and infrequent campaign activities (Asmui et al., 2019). 
This is consistent with a previous study conducted in one of the private universities in Bandung, Indonesia, students still throw garbage carelessly even though in place there is garbage pit (Anwar et al., 2017). Therefore, those factors showed the affective and cognitive environmental affect the students' attitude and 3R processes.

\section{R Processes}

3R processes are not new for many citizens including university students. In Malaysia, the trash bins equipped with three different colours widely provided by many university campuses and colleges as to mainly facilitate students to practice 3R. In addition, consumers claimed that the less the facilities provided, and the more inconvenience felt by them in carrying out the process of recycling, the lower would be the participation in recycling (Latif, Omar, Biding and Awang, 2013; Asmui et al., 2018). Littering education has been taken place since the students were in kindergarten and primary schools. However, the problematic point of view of today's generations is that they have the rights of limitless ownership without taking into account the responsibilities towards society and humanity (Astrom, 2011; Ashtankar, 2016; Asmui et al., 2018). This condition caused the efforts of government and university to achieve and maintain the cleanliness of campuses and colleges failed.

\section{The Relationship between Affective environmental, Students' Attitude and 3R}

Affective learning in environmental education in relation to individual attitudes is significant and has laid the groundwork that environmental education helps promote positive attitudes toward the environment (Gardner, 1983). Findings on several studies have shown that there were impacts of affection on attitude (Carrus et al., 2008). Moreover, there were also studies on the impact of affection on green behaviours (reduce, reuse and recycle) (Meneses, 2010). Furthermore, some studies findings show a more significant impact of affection towards consumers' green behaviour (Lee, 2009).

\section{Methodology}

This study is based on adapted questionnaire from the previous studies (Nameghi et al., 2013 \& Ehsaneh et al., 2012) targets students at higher learning university as the sample. The questionnaire used is divided into two parts where Part 1 accumulated by four sections such as the environmental affective (five items); environmental cognitive (six items); students' attitude (five items); and 3R (reduce, reuse, recycle) process (three items each), whereas Part 2 is a demographic section. The questions are in a five Likert-scale format range from 1 (strongly disagree) until 5 (strongly agree). The questionnaire was distributed and a total of 112 respondents completed the survey.

The data analyses were conducted by two steps using IBM-SPSS AMOS version 24 software including descriptive analysis and structural equation modelling. First, analysis of covariance structure was used to examine the mediation model and investigate the causal relations between the main variables. Second, mediation test procedures used to obtain estimated value of the indirect effects and to test their significance by using standardized regression weight with students' attitude used as mediating variable. The mediation occurs statistically if the indirect effect obtained is higher than the direct effect. 


\section{Reliability and Validity}

Reliability and validity were used in this study through unidimensionality, validity and reliability to ascertain or evaluate the fitness of the measurement models (Zainudin, 2015). Zainudin (2015) and Hair et al. (2010) stressed that unidimensionality is achieved when the measuring items have acceptable factor loading for the respective latent construct and the recommended factor loading value for latent construct is around 0.6 and above, and all in one direction. Secondly, validity is access through convergent validity, discriminant validity, and constructs validity. Convergent validity is achieved when the average variance extracted (AVE) is at least 0.5 , construct validity achieved for each of the fitness indexes, as shown in Table 1 for a required level, and discriminant validity achieved when the construct is free from redundant items and the correlation between exogenous constructs is at most 0.85 . Thirdly, reliability must satisfy two criterias; composite reliability (CR) achieved for CR at least 0.6 and AVE is at least 0.5 (Zainudin, 2015; Hair et al., 2010).

Table 1. The three categories of model fit

\begin{tabular}{|c|c|c|c|}
\hline $\begin{array}{l}\text { Name of } \\
\text { Category }\end{array}$ & $\begin{array}{l}\text { Name of } \\
\text { Index }\end{array}$ & Index Full Name & $\begin{array}{c}\text { Level of } \\
\text { Acceptance }\end{array}$ \\
\hline \multirow[t]{3}{*}{ Absolute Fit } & Chi-Square & Discrepancy Chi-Square & P-value $>0.05$ \\
\hline & RMSEA & $\begin{array}{l}\text { Root Mean Square of Error } \\
\text { Approximation }\end{array}$ & $<0.08$ \\
\hline & GFI & Goodness of Fit & $>0.09$ \\
\hline \multirow[t]{4}{*}{ Incremental Fit } & AGFI & Adjusted Goodness of Fit & $>0.09$ \\
\hline & $\mathrm{CFI}$ & Comparative Fit Index & $>0.09$ \\
\hline & TLI & Tucker-Lewis Index & $>0.09$ \\
\hline & $\mathrm{NFI}$ & Normal Fit Index & $>0.09$ \\
\hline Parsimonious Fit & Chisq/df & Chi-Square/ Degrees of Freedom & $<3.0$ \\
\hline
\end{tabular}


Figure. 1. Confirmatory factor analysis between variables

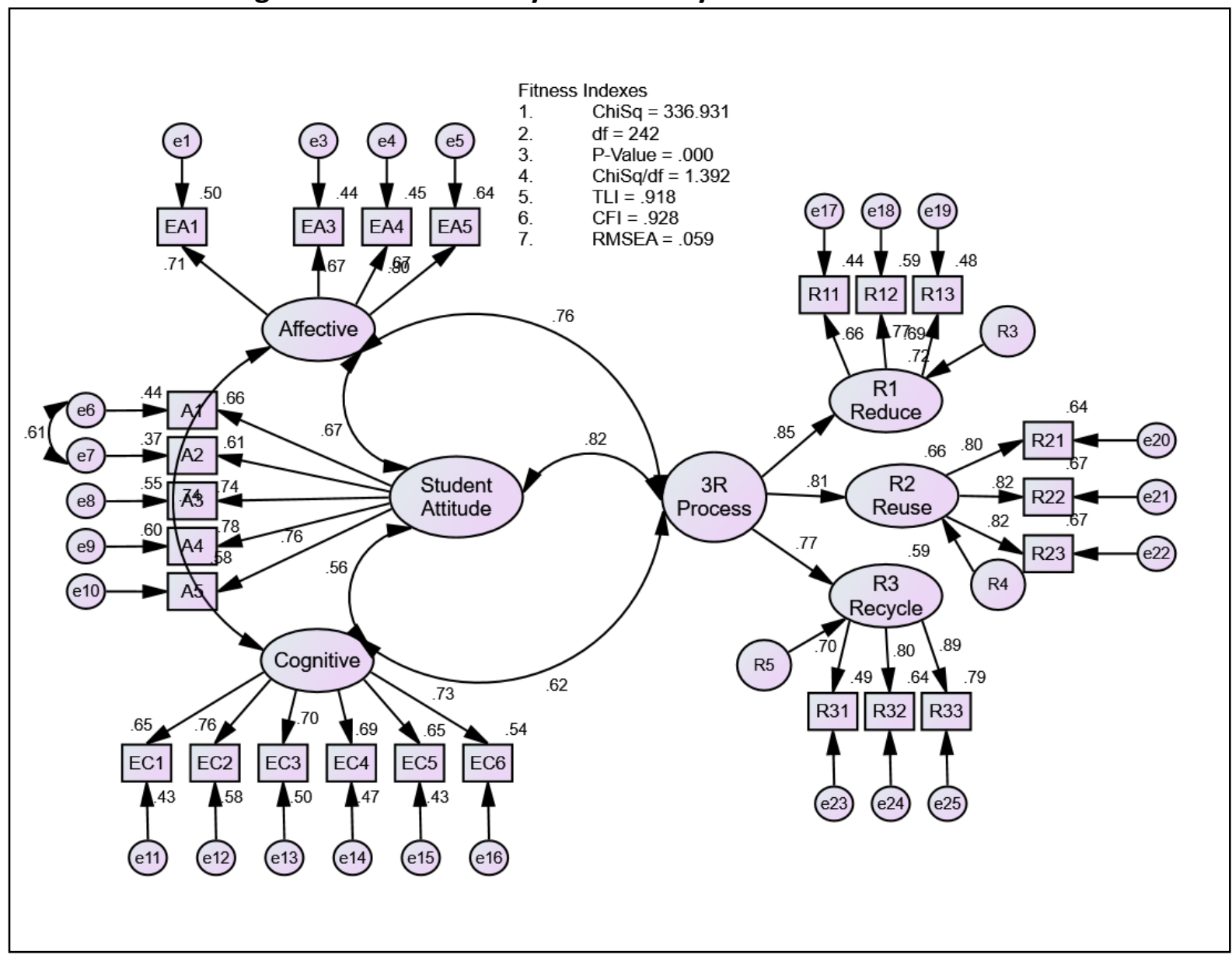

The goodness of measurement model fit was tested to examine how well the model fits the data is shown in Table 2.

Table 2. The goodness of measurement model fit

\begin{tabular}{lccc}
\hline $\begin{array}{c}\text { Name of } \\
\text { Category }\end{array}$ & $\begin{array}{c}\text { Name of } \\
\text { Index }\end{array}$ & Value Index & Result \\
\hline Absolute Fit & RMSEA & .059 & $\begin{array}{c}\text { Minimum value } \\
\text { achieved } \\
\text { Incremental Fit }\end{array}$ \\
CFI & .918 & $\begin{array}{c}\text { Minimum value } \\
\text { achieved } \\
\text { Minimum value } \\
\text { achieved }\end{array}$ \\
\hline Parsimonious Fit & Chisq/df & 1.392 & $\begin{array}{c}\text { Minimum value } \\
\text { achieved }\end{array}$ \\
\hline
\end{tabular}

Figure 1 shows all the paths with standardized regression coefficients has factor loadings at least 0.6 and all measurement in positive direction so that the unidimensional was achieved as suggested by Zainudin (2015) after removed labelled item EA2. In addition, convergent validity was also achieved because all AVEs is greater than 0.5 , all the fitness indexes of construct validity achieved as shown in Table 2 for a required level, and discriminant validity achieved because all construct is free from redundant items and the correlation between exogenous constructs is at most 0.85 (Zainudin, 2015; Hair et al., 2010). 


\section{Findings and Discussion}

In total 38 (33.9\%) male and 74 (66.1\%) female students aged less than 20 years old were involved in this study with all of them have experience in green practicing. The following Figure 2 shows the structural equation modelling between all the constructs.

Figure. 2. The measurement model between variables

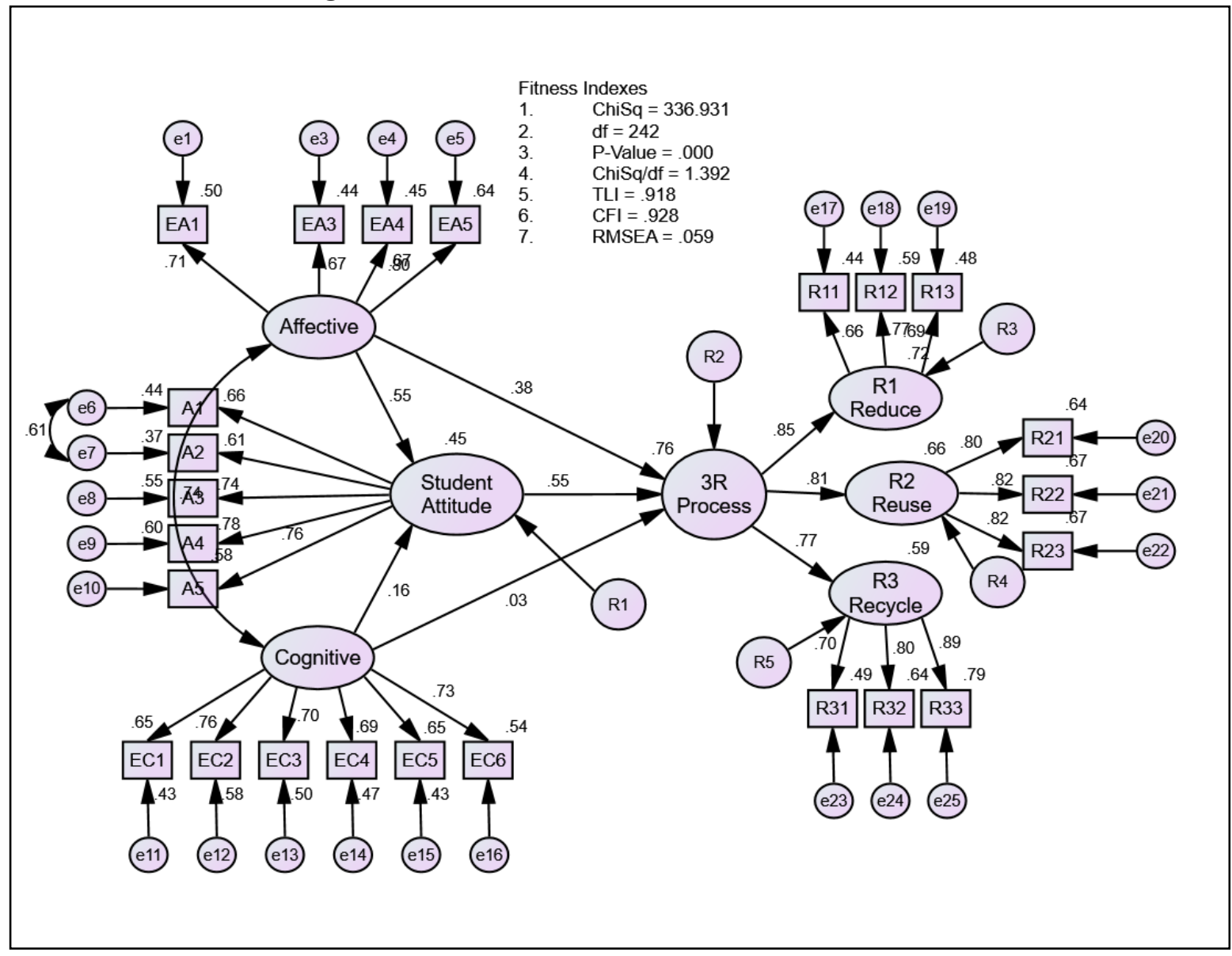

Table 3. The standardized regression weights and its significance for each path

\begin{tabular}{lccc}
\hline \multicolumn{1}{c}{ Hypothesis statement of Path Analysis } & Estimate & p-value & Result \\
\hline $\begin{array}{l}\text { H1: Environmental affective has significant } \\
\text { effect on students' attitude }\end{array}$ & .549 & .003 & Significant \\
\hline $\begin{array}{l}\text { H2: Environmental cognitive has significant } \\
\text { effect on students' attitude }\end{array}$ & .159 & .338 & $\begin{array}{c}\text { Not } \\
\text { Significant }\end{array}$ \\
\hline $\begin{array}{l}\text { H4: Environmental affective has significant } \\
\text { effect on 3R process }\end{array}$ & .376 & .037 & Significant \\
\hline $\begin{array}{l}\text { H4: Environmental cognitive has significant } \\
\text { effect on 3R process }\end{array}$ & .027 & .847 & $\begin{array}{c}\text { Not } \\
\text { Significant }\end{array}$ \\
\hline $\begin{array}{l}\text { H5: Students' attitude has significant effect } \\
\text { on 3R process }\end{array}$ & .553 & .000 & Significant \\
\hline
\end{tabular}

Firstly, the path between environmental affective and attitude among higher learning students is positive $(\theta=.549)$ indicated that students' attitude positively affected by environmental affective. The effect is significant at $5 \%$ level of significance ( $p$-value $=.003$ ) 
which is consistent to the previous studies by Mustapha et al. (2018), Carrus et al. (2008) and Gardner (1983). In contrast, the other path between environmental cognitive and students' attitude is not statistically significant at $5 \%$ level of significance $(B=.159, p$-value $=.338)$. It shows that this study only revealed that the environmental affective affected the students's attitude compared to previous study (Asmui et al., 2019; Anwar et al.,2017) which stated that the both elements affected the students' attitude.

In addition, environmental affective and students' attitude has significant effect on $3 \mathrm{R}$ (reduce, reuse, recycle) process at $5 \%$ level of significance $(b=.376, p$-value $=.037 ; b=.553$, $p$-value $<.001)$, but not significant effect occurred between environmental cognitive and $3 R$ process ( $p$-value $=.847)$. This study found that the students' attitude existed positive significant effect towards green behaviours (reduce, reuse and recycle) which consistent to Lee (2009) and Meneses (2010)

A mediating variable; students' attitude is responsible for the relationship between the predictor and the outcome. As stated earlier, students' attitude has been categorized as mediator variable on the relationship between environmental affective and the $3 \mathrm{R}$ process, also between environmental cognitive and the $3 R$ process. The test for mediator only meaningful if the direct effect is statistically significant at least at $5 \%$ level of significance. Since the direct effect between environmental cognitive and $3 R$ process is not statistically significant, therefore the mediation test will focus on environmental affective only. To examine the total direct and indirect effect of environmental affective on $3 R$ process through students' attitude, the following Figure 3 illustrate the procedure for testing mediation.

Figure 3 The standardized regression weight for the model

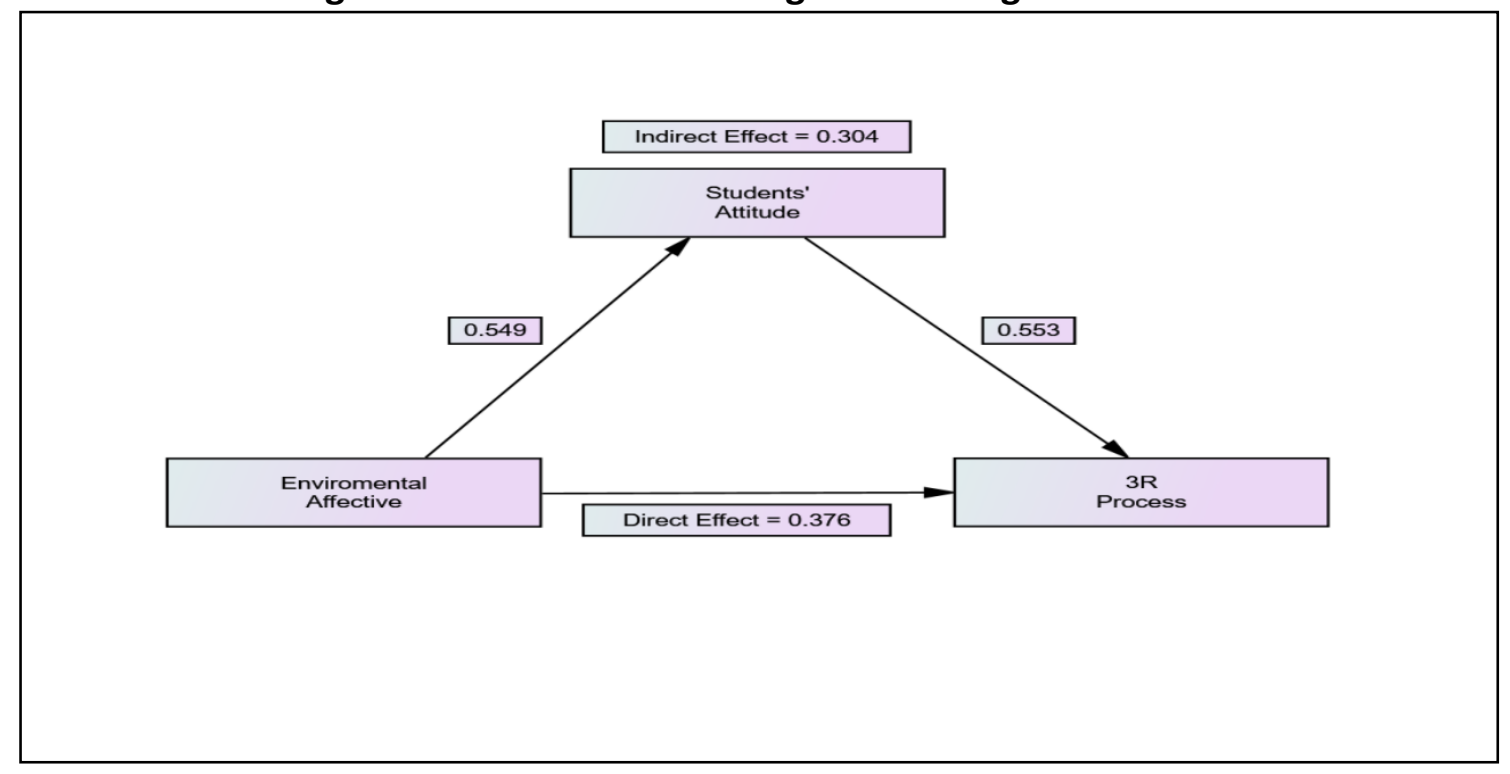

The result of direct effect between environmental affective and the $3 R$ process is 0.376 and the indirect effect between these two variables is 0.304 . This finding revealed that the direct effect is higher than indirect effect, which means that the mediation is not occur. As a result, it can be concluded that the higher learning institution students' attitude does not mediate the relationship between environmental affective and the $3 \mathrm{R}$ process.

\section{Conclusion and Recommendation}

The analysis showed that the environmental affective among the students is optimistic towards $3 R$ processes. This study also proved that the students have significant positive 
feeling towards $3 R$ practices because they exercised $3 R$ concepts correctly and surely. Due to this finding, the environmental affective among the university students is a significant predictor towards $3 R$ processes because the students' feeling shows their responsibilities towards the environment. This is consistent with the previous studies that environmental affection highly affected student's environmental attitude compared to the environmental cognition.

The analysis presented that the students' attitude has significant effect towards $3 R$ processes. This positive result indicated that their attitude is highly regulated to $3 R$ processes because they found that the $3 R$ practices are useful and rewarding to the ecological system. Therefore, the students positively reacted towards $3 R$ practices.

Thus, this study is able to validate the past researches on the link among students' attitude, environmental affective and $3 R$ processes. This validation shows that the university need to put priority on the issues relating to $3 R$ practices by continuing make efforts towards motivating the $3 \mathrm{R}$ practices among the students. It is also hoped that this study will inspire everybody, any agencies or relevant authorities to assist everyone in practicing $3 R$ through positive attitudes and showing positive culture of green practice. Future study can be conducted to identify the knowledge, attitude and perception of public towards green practices especially in making $3 R$ processes as positive habit.

\section{References}

Ashtankar, O. M. (2016). Islamic perspectives on environmental protection. International Journal of Applied Research, 2(1), 438-441.

Aström, H. Z. (2011). Paradigm shift for sustainable development: The contribution of Islamic Economics. Journal of Economic and Social Studies, 1(1), 73-82.

Latif, S. A., Omar, M.S., Bidin, Y. H., \& Awang, Z. (2013). Analyzing the effect of situational factor on recycling behavior in determining the quality of life. Journal of Asian Behavioural Studies, 3(8), 37-46.

Asmui, M., Mokhtar, N., \& Zaki, S.. (2018). To nuture hygiene culture among tertiary level students. Proceeding in The Third CHREST International Conference, 69-74.

Asmui, M., Mokhtar, N., \& Zaki, S.. (2019). The effects of awareness level on littering behaviour on campus: Family income as moderator. Proceedings of the Third International Conference on Computing, Mathematics and Statistics (iCMS2017), 465473. doi: 10.1007/978-981-13-7279-7_58

Anwar, T. (2017). Is it hard for college student to throw trash, Conference paper. Retrieved from http://www.researchgate.net/publication/321952190. doi $10.1145 / 3149572.3149612$

Keep Louisiana Beautiful. (2017). Potential value in litter education in schools litter education in school. Retrieved from https://keeplouisianabeautiful.org/wpcontent/uploads/2017/04/Litter-education-white-paper.pdf.

Cardon, M. S., Foo, M., Shepherd, D., \& Wiklund, J. (2012). Exploring the Heart: Entrepreneurial Emotion is a Hot Topic. Entrepreneurship Theory and Practice, 36(1), 1-10. https://doi.org/10.1111/j.1540-6520.2011.00501.x.

Cardon, M. S., Foo, M., Shepherd, D., \& Wiklund, J. (2012). Exploring the Heart: Entrepreneurial Emotion is a Hot Topic. Entrepreneurship Theory and Practice, 36(1), 1-10. https://doi.org/10.1111/j.1540-6520.2011.00501.x 
Carrus, G., \& Passafaro, P.. (2008). Emotions, habits and rational choices in ecological behaviours: The case of recycling and use of public transportation. Journal of Environmental Psychology, 28, 51-61. http://dx.doi.org/10.1016/j.jenvp.2007.09.003

Dieser, O. (2015). Cognitive achievements, attitudes and associations: an experience-oriented intervention study at the extracurricular learning place National Park (University of Bayreuth, Bayreuth, Germany). (Ph.D. dissertation). Retrieved from https://epub.unibayreuth.de/2072/.

Gardner, H. (1983). Frames of mind: The theory of multiple intelligences. New York: Basic Books.

Schumm, M. F., \& Bogner, F. X. (2016). The impact of science motivation on cognitive achievement within a 3-lesson unit about renewable energies. Studies in Educational Evaluation, 50, 14-21. https://doi.org/10.1016/j.stueduc.2016.06.002

Kurczewska, A., Kyro, P., Lagus, K., \& Lindh-Knuutila, T.. (2017). The interplay between cognitive, conative, and affective constructs along the entrepreneurial learning process. Education and Training, 60 (7/8), 891-908. Retrieved from https://doi.org/10.1108/ET09-2016-0148

Mustapha, M., Asmui, M., Zaki, S., \& Razali, S. (2018). Assessing the relationship between students' attitude toward environmental affective and cognitive in green practice, Symposium proceeding: National Academic Symposium of Social Science (NASSc2018), 290-296, elSBN: 978-967-16271-8-1.

Meneses, D. (2010). Refuring in heuristics and in recycling promotion. Journal of business research, 63, 104-110. http://dx.doi.org/10.1016/j.jbusres.2009.02.002

Lee, K. (2008). Opportunities for green marketing: young consumers. Marketing Intelligence \& Planning, 26 (6). http://dx.doi.org/10.1108/02634500810902839

Hines, J. M., Hungerford, H. R., \& Tomera, A. N. (1987). Analysis and synthesis of research on responsible environmental behaviour: A meta-analysis. Journal of Environmental Education, 18(2), 1-8.

Kals, E., \& Maes, J. (2002). Sustainable development and emotions. Psychology of Sustainable Development (eds.P.Schmuck and W.P. Schultz), Kluwer Academic Publishers, Boston, pp.97-122; Osbaldiston, R. and Sheldon, K.M. (2002) op.cit

Kollmuss, A., \& Agyeman, J. (2002). Mind the gap: Why do people act environmentally and what are the barriers to pro-environmental behavior?. Environmental Education Research, 8(3), 239-260.

Fettahlioglu, P. (2016). Environmental affective dispositions scale (EADS): The study of validity and reliability and adaptation to Turkish. International Journal of Environmental and Science Education, 11 (10), 3179-3199.

Roth, C. E. (1992). Environmental literacy: Its roots, evolution and directions in the 1990s. Columbus OH: ERIC Clearinghouse for Science, Mathematics and Environmental Education. 